Avalaible online: https://ejournal.iai-tribakti.ac.id/index.php/pgmi

Article doi: https://doi.org/10.33367/jiee.v3i2.1946

Submission: 2021-09-12 Review: 2021-09-28 Revision: 2021-09-28 Accepted: 2021-09-28

\title{
Online-Based Distance Learning During Covid-19 Pandemic at Primary School
}

\author{
Tenika Illananingtyas ${ }^{1}$ \\ ${ }^{1}$ Institut Agama Islam Tribakti Kediri \\ 1 tenikaillananingtyas07@gmail.com
}

\begin{abstract}
The Indonesian government is currently facing a Covid-19 pandemic that is still beyond its control. From print media to electronic media, the mass media continues to report on the number of victims infected with this virus, and the number is declining. One of the predictive steps to prevent the spread of this virus is to maintain social distancing. As a formal educational institution, the school responded quickly to this situation. The school does not hope that by changing the face-to-face learning mode, the virus will spread in its environment. i.e. through distance learning or online learning (online) Therefore, this is the task of the teacher, that is, to be able to create various activities in online learning that can attract students' interest in learning. Especially learning English requires not only theory, but also a lot of practice. Therefore, interactive learning in the form of activities is required to allow students to actively participate in the online learning process. This research aims to obtain important information about the effectiveness of online distance learning (PJJ) for primary schools in Kediri City. The research methods used descriptive qualitative methods to 20 respondents. According to the analysis data, the research results show that online distance learning for elementary schools is considered to be quite effective.
\end{abstract}

Keyword: Online Distance Learning, Covid-19 Pandemic, Primary School

Abstrak
Pemerintah Indonesia saat ini sedang menghadapi pandemi Covid-19 yang
masih di luar kendali. Dari media cetak hingga media elektronik, media massa
terus memberitakan jumlah korban yang terinfeksi virus ini, dan jumlahnya
terus menurun. Salah satu langkah prediktif untuk mencegah penyebaran
virus ini adalah dengan menjaga jarak sosial. Sebagai lembaga pendidikan
formal, sekolah merespon dengan cepat situasi ini. Pihak sekolah tidak
berharap dengan mengubah mode pembelajaran tatap muka, virus akan
menyebar di lingkungannya, yaitu dengan melalui pembelajaran jarak jauh
atau pembelajaran online. Oleh karena itu, inilah tugas guru yaitu mampu
menciptakan berbagai aktivitas dalam pembelajaran online yang dapat
menarik minat siswa untuk belajar. Apalagi belajar bahasa Inggris tidak hanya
membutuhkan teori, tetapi juga banyak latihan. Oleh karena itu, pembelajaran
interaktif dalam bentuk kegiatan diperlukan agar siswa dapat berpartisipasi
aktif dalam proses pembelajaran online. Penelitian ini bertujuan untuk
memperoleh informasi penting tentang efektivitas pembelajaran jarak jauh
(PJJ) online untuk sekolah dasar di wilayah Kota Kediri. Metode penelitian
yang digunakan adalah metode deskriptif kualitatif terhadap 20 responden.
el Bidayah: Journal of Islamic Elementary Education
volume 3, Nomor 2, September 2021


Berdasarkan data analisis, hasil penelitian menunjukkan bahwa PJJ online untuk SD dinilai cukup efektif.

Kata Kunci: Pembelajaran Jarak Jauh, Pandemi Covid-19, Sekolah Dasar

\section{Introduction}

The COVID-19 pandemic has been affecting the world of education since mid-March 2020. The government of Indonesia has taken a choice in the form of a new policy for the implementation of learning. Students who normally study in a classroom with teachers or lecturers, but during a pandemic, learning activities are done out at home online, or through an online learning system. Online, learning activities are also required. This is done to avoid extensive transmission as a result of large-scale contacts. Physical separation is one of the more promising ways for breaking the disease's transmission chain. ${ }^{1}$

This is in accordance with the Minister of Education and Culture's circular letter No. 4 of 2020, which outlines how education policies should be implemented during the emergency phase of the Corona Virus Disease (Covid-19) pandemic. As a result, learning activities during the epidemic will take place on personal computers (PCs), laptops, and other devices that are connected to the internet network. Educators can use social media groups such as Telegram, Instagram, WhatsApp, Google meetings, Google Classroom, Zoom, and others to complete the same learning at the same time. For some students and educators, face-to-face online learning is a novel learning experience that has never occurred before in the world, because the teaching and learning process has a lways been carried out in a classroom setting, particularly for primary school kids. Of course, this elicits a wide range of reactions in the community, including those from kids, teachers, and parents. This teaching technique offers a number of advantages and disadvantages. On the one hand, it allows students and professors to stay in touch and interact without having to meet in person. Because this method delivers a virtual learning experience, which is something unique in the learning process, this

\footnotetext{
${ }^{1}$ Daheri dan D. Mirzon, "Efektifitas WhatsApp sebagai Media Belajar Daring," BASICEDU 4, no. 4 (2020). 
online face-to-face learning provides a fun learning experience at the start. However, the application of this learning has a negative influence on elementary school pupils over time, with many students losing interest and concentration in learning due to boredom and boredom when studying. Furthermore, youngsters in elementary school, ages 6 to 12, have the ability to focus on a task for only 30-45 minutes. Concentration, according to Manurung, is the ability to focus one's mind on a certain task. Furthermore, many students believe that this learning is too routine and dull, especially because many lecturers merely supply materials and assignments in the online teaching and learning process. ${ }^{2}$ As a result, it is the responsibility of teachers to design varied activities in online learning that would pique students' interest in learning.

Learning effectiveness, according to Afifatu Rohmawati (Rohmawati, 2015), is one of the quality standards of education that is commonly measured by the attainment of goals. It can also be construed as precision in dealing with a problem, which is commonly referred to as doing the correct thing. Meanwhile, stated that effective learning is a combination of human resources, facilities, materials, adequate equipment, and procedures aimed at changing students' behavior in a better direction in accordance with their potential and differences in order to achieve the learning objectives set. Meanwhile, according to another viewpoint, successful learning is learning that allows students to learn on their own and engage in as many activities as feasible. Self-study opportunities and activities should be made available to students in as many ways as possible to assist them understand the topics or instructional materials being studied. ${ }^{3}$ According to the above viewpoint, the effectiveness of learning seems to be an indicator of the effectiveness of a process of communication between interaction between students and teachers in educational contexts in order to fulfill the instructional objectives themselves. ${ }^{4}$ As a result, student actions during the learning process, student responses to

\footnotetext{
${ }^{2}$ M. P. Manurung dan D. Simatupang,

“Meningkatkan Konsentrasi Anak Usia 5-6 Tahun Melalui Penggunaan Metode Bercerita di TK ST Theresia Binjai," Jurnal Usia Dini 5, no. 1 (t.t.). 210
}

${ }^{3}$ O. Hamalik, Psikologi Belajar dan Mengajar (8th ed.) (Sinar Baru Algen sindo, 2010).

${ }^{4}$ E. Mulyasa, Manajemen Pendidikan Anak Usia Dini (Pertama). (Remaja Rosdakarya, 2012).

el Bidayah: Journal of Islamic Elementary Education Volume 3, Nomor 2, September 2021 
learning, and mastery of ideas or educational materials can all be indicators of learning efficacy. To achieve an efficient and effective learning concept, there must be a mutually beneficial relationship between students and teachers in order to achieve a common goal; additionally, it must be tailored to the conditions of the classroom setting, environment and equipment, and also the having to learn media required to support all aspects of student development. ${ }^{5}$ found that when the essential components of learning are met, namely interactive, adjustable, discursive, and reflective with good aspects when connected with the educational environment, online learning becomes very successful.

This section contains the background research context, research problems, and research with relevant and up-to-date theoretical studies and previous research, explaining the research framework, as well as the theoretical foundations and approaches used.

Especially in the case of learning English, which requires not just theory but also a lot of practice, interactive learning that actively involves students in the learning process is required. Teachers must have new ideas for building effective online learning by leveraging online learning applications while teaching English to primary school pupils, because English subjects are difficult to teach for elementary students, and not all students are interested in studying English. Investigate it. As a result, amid this Covid-19 pandemic, teachers must devise a variety of effective learning activities to pique kids' interest in studying.

Distance learning (PJJ) is defined as learning that takes place through the internet and allows for interaction between teachers and students or learners. In the framework of PJJ, interactions between professors and students are not face-to-face, that is, they are not face-to-face even if they are in different places and separated by a great distance. ${ }^{6}$

Then, according to Muhammad Fajrul Bahri learning is defined as a technique or approach used by someone

\footnotetext{
${ }^{6}$ Prawiyogi, Anggi, dan D. Giri, “Efektifitas Pembelajaran Jarak Jauh Terhadap Pembelajaran Peserta didik di SDIT Purwakarta," JPD: Jurnal Pendidikan Dasar 11, no. 1 (t.t.).
}

\footnotetext{
${ }^{5}$ Riskey Oktavian dan Riantina Fitra Aldya, "Efektivitas Pembelajaran Daring Terintegrasi di Era Pendidikan 4.0," Didaktis: Jurnal Pendidikan dan Ilmu Pengetahuan 20, no. 2 (12 Mei 2020), https://doi.org/10.30651/didaktis.v20i2.4763. el Bidayah: Journal of Islamic Elementary Education Volume 3, Nomor 2, September 2021
} 
to conduct learning activities. teaching methods have provided

Furthermore, the concept of learning can be interpreted as an interactive process involving teachers and students with the goal of acquiring knowledge, attitudes, and talents or skills. ${ }^{7}$

According to several research findings summarized from Prawiyogi, et al, PJJ has several advantages, including: (1) the relevance of teaching materials to the times, (2) the distribution of education throughout the country by unlimited capacity because there is no need for a classroom, (3) not limited by time, and (4) students to choose the topic of education. ${ }^{8}$

Learning is aided by websites and blogs, which increases the effectiveness of online-based learning. ${ }^{9}$ Meanwhile, according to Laksmi Dewi, the online system in learning activities has a lot of promise as an alternate problem solving method for improving students' pedagogic competencies. Similarly, research conducted by Eko Kuntarto concluded that online-based

\footnotetext{
${ }^{7}$ M. F. Bahri, “Kemampuan Berpikir Kritis Menggunakan Tes Terintegrasi Agama dan Sains dalam Pembelajaran PAI di SMA," Edukasi Islami: Jurnal Pendidikan Islam 8, no. 2 (2019).

8 Prawiyogi, Anggi, dan Giri, "Efektifitas Pembelajaran Jarak Jauh Terhadap Pembelajaran Peserta didik di SDIT Purwakarta."

${ }^{9}$ Nurul Lailatul Khusniyah dan Lukman Hakim, “EFEKTIVITAS PEMBELAJARAN BERBASIS DARING:

INGGRIS," Jurnal Tatsqif 17, no. 1 (10 Juli 2019): 19-33, https://doi.org/10.20414/jtq.v17i1.667. ${ }^{10}$ E. Kuntarto, “Keefektifan Model Pembelajaran Daring Dalam Perkuliahan Bahasa Indonesia di Perguruan tinggi," Journal Indonesian Language Education and Literature 3, no. 1 (2017). 
from respondents. Display data (data presentation), visualization, and conclusion visualization are all part of an interactive cycle for discussing research findings (conclusions). Peer reviewers were used in this study to confirm the findings or research results, in addition to descriptive reviews, in order to maintain the impartiality and validity of the findings in the area.

\section{Result and discussion}

\section{Result}

Virtual communication is a form of learning that makes use of the internet network. This aligns with definition of online learning as a learning environment offered and facilitated by the internet. During the Covid-19 time, there are two forms of online learning: online learning and online learning that combines virtual face-to-face interaction with an internetconnected conferencing application. ${ }^{11}$

It can be seen that the primary source of information for instructors about online distance learning is from school principals and supervisory, indicating that communication between principals and supervisors and teachers progressed well during Covid 19, both in terms of guidance and monitoring.

Then, 85.5 percent of teachers are able or capable of using information technology in online learning, while 13.3 percent are proficient. Between 61 and 80 percent of teachers can utilize IT (IT literacy), with 44.9 percent unable to do so. Furthermore, a number of teachers who were fluent in using IT ranged from 81 to 100 percent, and 33.6 percent of teachers were proficient in using IT.

Students and parents of students contribute in the effectiveness of the deployment of online learning during the pandemic situation. A majority of public primary schools in Kediri already have online learning facilities, including 20 schools (71.4\%) that have Wifi networks established, 12 schools (4.7\%) that have blogs, 15 schools (13.7\%) that already have websites, and 18 schools $(22.3 \%)$ that have employed online learning programs. This is seen as one of the most important components in the implementation of PJJ, particularly for instructors in performing out their primary responsibilities as teachers.

\footnotetext{
${ }^{11}$ Isai Amuthan Krishan dkk., "Challenges of Learning English in 21st Century: Online vs. Social Sciences and Humanities (MJSSH) 5, no. 9 (31 Agustus 2020): 1-15, Traditional During Covid-19," Malaysian Journal of https://doi.org/10.47405/mjssh.v5i9.494. 


\section{Oleh: Tenika Illananingtyas}

Facebook, Whatsapp, Telegram, and Instagram are all used by 96 percent of teachers. Other categories include 17.7\% using Google Meet, 25.2\% using Microsoft Team, 35\% using Google Classroom, 10\% using E-learning, and others. In general, social media is still used in programs used by teachers for distance learning in primary schools.

\section{Discussion}

There are some factors that teachers encounter as roadblocks in implementing online learning. Limited credit/quota, limited student facilities, and some pupils still stammer when it comes to using instructional technologies are just a few of the challenges.

Writing and speaking abilities can be taught to primary school pupils through a variety of fun learning activities. The teacher serves as an instructor and facilitator for students while they engage in a series of virtual learning activities. Students are required to participate actively in these activities.

Teachers can use the one of onferencing element suh as Zoom Meeting application in this exercise. The steps are as follows: The teacher shows a picture of one object, such as animals, fruit, or food, and instructs students to write a few phrases describing the object in the Chat column. The teacher then invites all students to read the answers they have made in the Chat column and correct the answers together. Students can practice thinking and writing a topic in written form in this learning exercise. Students must also ponder before writing down their answers, as writing involves a thinking processes.

Teachers' distance learning applications in elementary schools still use social media. Because the teacher receives relatively little feedback to measure the level of students' capacity to absorb the teaching content, it is possible to make learning activities less effective. It is critical that the school do a full evaluation in order to discover a better suitable answer.

Then, in short video viewing, the teachers can use the screen share function in the Zoom Meeting program for this exercise. The following are some of the measures that can be taken by using the screen sharing feature, the teacher first presents one video animation with brief stories. The teacher can then direct pupils to write in the chat column whether they know all the answers towards the questions that will be asked when the video has done el Bidayah: Journal of Islamic Elementary Education Volume 3, Nomor 2, September 2021 
running. Following that, the teacher asked the kids some spoken questions. Finally, the teacher and students collaborated to revise the responses that they had written. Students can learn to concentrate on watching movies and to think rapidly in order to respond to challenges in this learning experience.

In essence, online learning would have to be enjoyable, because when we learn while joyful, the lesson is more easily assimilated by the brain. Especially for primary school students, who have a stronger desire to play than to acquire. This is also true in English classes, as not all pupils have the same abilities and capabilities when it comes to acquiring information. While acquiring the four parts of language skills, including reading, speaking, listening, and writing, is the focus of this English class. Because both writing and speaking are human ways of transmitting messages, the only difference is the format in which the content is delivered. Writing is a method of conveying information in writing, whereas speaking is a method of conveying information vocally. These are the two most crucial qualities in English is her first language. Many learning activities, such as writing item descriptions, watching short movies, el Bidayah: Journal of Islamic Elementary Education Volume 3, Nomor 2, September 2021 and answering worksheets, can be employed in online learning using conference programs. To properly meet the goals of learning English, several of these e - learning enables must be tailored to students' ability. Creativity and innovation are essential for creating engaging online learning during the Covid-19 pandemic. Teachers must continue to look for and experiment with new and creative ways to develop English classes in order to maintain students' interest and excitement while learning online.

\section{Conclusion}

Online learning, which took occurred during the Covid-19 pandemic, posed a significant challenge for students and teachers, as the learning process is carried out digitally via the use of apps connecting via the internet network. Teachers need to be able to establish virtual face-to-face learning that can draw kids' interest in understanding by designing interactive learning activities to sharpen children's English skills when using online English learning for elementary students. As a result, the teacher performs a significant role as a facilitator, directing students to participate in classroom activities that the instructor has created in this manner. The most important thing 
therefore for teacher to focus on before beginning is fundamental English abilities. The teacher must guarantee that all virtual learning activities will help students enhance their fundamental English language proficiency when creating this interactive learning activity. Aside from that, other activities provide students with useful learning experiences and increase their enthusiasm in studying English.

There is an online learning platform that is routinely utilized to collect assignments, provide connections to material enrichment, perform face-to-face activities, and other elaborating activities, and record such activities. Video conference activities should be done more frequently, and in this instance, an effort should be made to increase the quality of infrastructure possessed by students, either through government or institution supports, such as scholarships.

The teacher's online-based remote learning model is more typically in the form of giving assignments. This is understandable given that students who participate in online learning are perceived to be less active and creative, therefore professors value it more if the 216 development of teaching materials is presented in the form of structured assignments, allowing students to take ownership of the process. According to respondent data, 75.1 percent of primary school children in the City of Kediri are enthusiastic about participation in the online-based PJJ for the assessment category.

Teachers and students faced a number of challenges in implementing online PJJ, including a lack of resources or online media, quota restrictions, and some students who struggled with technology. During the COVID-19 epidemic, the frequency and length of online PJJ performed by teachers was fairly high (65.9\%), with a period of evaluation of between 1-2 hours of lessons.

\section{References}

Bahri, M. F. “Kemampuan Berpikir Kritis Menggunakan Tes Terintegrasi Agama dan Sains dalam Pembelajaran PAI di SMA." Edukasi Islami: Jurnal Pendidikan Islam 8, no. 2 (2019).

Daheri, dan D. Mirzon. "Efektifitas WhatsApp sebagai Media Belajar Daring." BASICEDU 4, no. 4 (2020).

Hamalik, O. Psikologi Belajar dan Mengajar (8th ed.). Sinar Baru Algen sindo, 2010.

Khusniyah, Nurul Lailatul, dan Lukman Hakim. "EFEKTIVITAS PEMBELAJARAN BERBASIS DARING: SEBUAH BUKTI PADA 
PEMBELAJARAN BAHASA

INGGRIS." Jurnal Tatsqif 17, no. 1

(10 Juli 2019): 19-33.

https://doi.org/10.20414/jtq.v1

$7 \mathrm{i} 1.667$.

Krishan, Isai Amuthan, Hee Sio Ching,

Selvajothi Ramalingam,

Elanttamil Maruthai, Pushpa

Kandasamy, Geraldine De Mello,

Saravanan Munian, dan Wong

Woei Ling. "Challenges of

Learning English in 21st

Century: Online vs. Traditional

During Covid-19." Malaysian

Journal of Social Sciences and

Humanities (MJSSH) 5, no. 9 (31

Agustus 2020): 1-15.

https://doi.org/10.47405/mjssh

.v5i9.494.

Kuntarto, E. “Keefektifan Model

Pembelajaran Daring Dalam

Perkuliahan Bahasa Indonesia di

Perguruan tinggi." Journal

Indonesian Language Education

and Literature 3, no. 1 (2017).

Manurung, M. P., dan D. Simatupang.

"Meningkatkan Konsentrasi

Anak Usia 5-6 Tahun Melalui

Penggunaan Metode Bercerita di

TK ST Theresia Binjai." Jurnal

Usia Dini 5, no. 1 (t.t.).

Mulyasa, E. Manajemen Pendidikan

Anak Usia Dini (Pertama).

Remaja Rosdakarya, 2012.

Oktavian, Riskey, dan Riantina Fitra

Aldya. "Efektivitas Pembelajaran

Daring Terintegrasi di Era

Pendidikan 4.0." Didaktis: Jurnal

Pendidikan dan Ilmu

Pengetahuan 20, no. 2 (12 Mei

2020).

https://doi.org/10.30651/didak

tis.v20i2.4763.

Prawiyogi, Anggi, dan D. Giri.

"Efektifitas Pembelajaran Jarak

Jauh Terhadap Pembelajaran

Peserta didik di SDIT

Purwakarta." JPD: Jurnal

Pendidikan Dasar 11, no. 1 (t.t.). 